риалы краевед. конф. / сост. В.Е. Николаев. Нерехта, $2007.142 \mathrm{c}$.

5. Костромская усадьба / Т.В. Иенсен, И.Ю. Кондратьева, Д.Б. Ойнас, А.И. Сорокин. Кострома,2005.420 с.

6. Головина Т.Н. Сады помещиков средней руки в 1820-1830-х гг. // Русская усадьба: Сб. о-ва изучения русской усадьбы: М., 2009. Вып. 15 (31). С. 134-142.

7. Волкова О.М., Нотов А.А. О флоре усадебных парков Торжокского района Тверской области // Вестник ТвГУ. Сер. «Биология и экология». 2006. Вып. 2. C.96- 100 .

8. Елисеенко Е.П. Флористические находки в усадебных парках Брянской области // Изучение и охрана флоры Средней России. М., 2010. С. 64-66.

9. Парахина Е.А., Киселева Л.Л. Современное состояние дендрофлоры парков в дворянских усадьбах Орловской области // Бюл. МОИП. 2007, Т. 112. Вып. 4. С. 51-57.

10. Плотникова Л.С. Значение старинных парков в охране генофонда и инродукции древесных растений // Бюлл. гл. ботан. сада. 1992. Вып. 165. С. 3-6.

11. Аксанова г.Ф. Дендрарий Аветисяна-лесокультурный памятник природы // Вестник Оренбургского гос. ун-та. 2008. №87. С. 25-28.

12. Борисова Е.А. Редкие виды растений в усадебных парках Ивановской области // Экология и культура: от прошлого к будущему. Материалы IV межрегион. науч.прак. конф. Ярославль: Индиго, 2010. С. 38-45.

13. Борисова Е.А., Сенюшкина И.В. Усадебный парк
«Студеные ключи» // Историко-культурный и природный потенциал кинешемского края. Развитие регионального туризма. Кинешма, 2012. С. 169-173.

14. Борисова Е.А. Шилов М.П., Касаткина С.В. Характеристика дворянской усадьбы в с. Корнилово // Историко-культурный и природный потенциал кинешемского края. Кинешма, 2014. С. 254-258.

15. Convention on the Conservation of European Wildlife and Natural Habitats, Bern, 19.IX.1979 Appendix I // Council of Europe. ETS 104 / Convention on the conservation of European Wildlife and Nature.

16. Красная книга Ивановской области. Т. 2: Растения и грибы / В.А. Исаев, Е.А. Борисова, М.А. Голубева и др. / под ред. В.А. Исаева. Иваново: ПресСто, 2010. 192 с.

17. Борисова Е.А., Голубева М.А. Дополнения к флоре Ивановской и Костромской областей // Ботан. журн. 2006. Т. 91, №2. С. 337-342.

18. Борисова Е.А. Адвентивная флора Ивановской области. Иваново: Иван. гос. ун-т, 2007. 188 с.

19. Борисова Е.А Особенности распространения инвазионных видов растений по территории Верхневолжского региона // Российский журн. биологических инвазий. 2010, №4. С. 2-9 /http://www/ sevin.ru/invasjour/issues/2010_4.html.

20. Тремасова Н.А., Борйсова Е.А., Борисова М.А. Сравнительный анализ инвазионных компонентов флор пяти областей Верхневолжского региона // Ярослав. пед. вестник. Т. 3 (Естественные науки), №4. 2013. С. 171-177

(C) 2015

\title{
FLORA OF THE IVANOVO REGION FARMSTEAD PARK “GRIDINO”
}

\author{
E.A. Borisova, Doctor of Biological Sciences, Associate Professor, \\ Head of the General Biology and Physiology Department \\ Ivanovo State University, Ivanovo (Russia)
}

Annotation. Data about flora of Ivanovo old region farmstead park "Gridino" are presented. Park and reservoir belong to Ivanovo region special protected territories-natural monument. Historical information about manufacturer farmstead of M.A. Pavlov and park planning are briefly reported. Modern park flora consists of 270 vascular plant species from 5 classis, 94 families and 146 genera. Asteraceae-32 species (11,9\%), Rosaceae-29 species (10,7\%), Poaceae-24 species (8,9\%) are leading families of the park flora. 1 species (Agrimonia pilosa) included in to Convention on the Conservation of European Wildlife, 3 rare species (Abies sinirica, Cornus alda, Deschampsia flexuosa)-in to regional Red date book are characterized. Some decorative arboreal (woody) species (Thuja occidentalis, Larix sibirica, Alnus incana forma pinnatifida, Populus alba, Caragana arborescens, Crataegus sanguine and other) species and grassy introduced plants (Hieracium murorum, Myosotis sylvatica, Phyteuma spicatum and other) are described. Examples of alien plant species spreading on territory of the park are given. Events for green plantations improvement are listed. Farmstead park "Gridino" is important object for regional biological diversity conservation and rare plan protection. Large recreational, educational and informative functions of the park are shown.

Keywords: old farmstead parks; flora; rare plant species; ornamental introduced plants; Ivanovo region.

\section{УДК 582.929.4:502.7 ДИКОРАСТУЩИЕ ВИДЫ МЯТЫ КАК НОСИТЕЛИ ГЕНОВ УСТОЙЧИВОСТИ К НЕБЛАГОПРИЯТНЫМ ФАКТОРАМ ОКРУЖАЮЩЕЙ СРЕДЫ}

(C) 2015

Л.А.Бугаенко, доктор биологических наук, профессор, профессор кафедры биологии, экологии и
Крымский инженерно-педагогический университет, Симферополь (Россия)

Аннотация. Показано, что дикорастущие виды мяты могут являться носителями генов морозоустойчивости и устойчивости к ржавчине, которая вызывается грибом Puccinia menthae Pers. Перспективным для создания устойчивых сортов является метод межвидовой гибридизации с использованием культивируемых видов-Mentha piperita L. и Mentha canadensis L., а также дикорастущих видов-Mentha aquatica L., Mentha spicata L. и Mentha longifolia (L.) Nathh. Выявлены доноры устойчивости к ржавчине-M. canadensis K60 (4п) и M. aquatica К6, которые в широком спектре комбинаций обеспечивают устойчивость к ржавчине основной массы гибридного потомства.

Показано, что межвидовая гибридизация у мяты при соответствующем подборе родительских пар является ценным методом создания устойчивых к ржавчине (Puccinia menthae Pers) высокопродуктивных гибридов. Подтвержден моногенный характер наследования иммунности к Puccinia menthae Pers и определен генотип родительских форм M. canadensis, M..aquatica, M.spicata по гену S. Наличие доминантных (S) или рецессивных аллелей (s) в гомозиготном (SS, SSSS, ss) или гетерозиготном состоянии (Ss, SSss) определяет выраженность этого признака в гибридном потомстве F1.

Установлено, что в F1 межвидовых гибридов от скрещивания аллополиплоидной формы перечной мяты с морозоустойчивыми растениями M. spicata признак морозоустойчивости наследуется в основном по промежуточному типу, однако до $30 \%$ растений приближается по этому признаку к морозоустойчивому родителю. Самарский научный вестник. 2015. № 2(11) 
Это указывает на возможность получения межвидовых гибридов с повышенной морозоустойчивостью при указанном типе скрещиваний.

Для создания гибридов с повышенной морозоустойчивостью перспективно использование в межвидовых скрещиваниях морозоустойчивых форм $M$. spicata K42, К65, линий S1 и S2, полученных от самоопыления K65 (2.8.I4, 9.37.34), а также полиплоида M.canadensis K60.

Создан генофонд дикорастущих видов и форм мяты, в котором представлены генотипы, обладающие генами устойчивости к ржавчине и пониженным температурам

Ключевые слова: межвидовая гибридизация; виды мяты; устойчивость к ржавчине; морозоустойчивость; гены устойчивости; генофонд; полиплоиды.

Постановка проблемы. Род Mentha L. принадлежит к семейству Lamiaceae, которое включает около 5600 видов и считается одним из наиболее сложных в систематическом отношении. И к настоящему времени нет единой точки зрения на объем рода Mentha. Однако, что касается систематики дикорастущих и культивируемых представителей рода Mentha флорь СНГ, наиболее объективной и удовлетворяющей современным правилам номенклатуры, является система, разработанная в 1972 году В.В. Макаровым [1] Этим автором определено, что на территории (СНГ) существует 8 «чистых» видов: M. pulegium L., M. micrantha (Fisch. ex Benth) Litw., M.arvensis L., M. canadensis L., M. dahurica Benth, M. Aquatic L., M. spicata L. emend Nathh., M. longifolia (L.) Nathh., а также 6 гибридных: $M$. $x$ carinthiaca Host., M. $x$ dalmaticaca Taush., M. $x$ dumetorum Shultes, M. x gentilis L., M. x piperita L., M. x werticillata L. Перечисленные виды объединены в два подрода: Mentha и Pulegium. Наиболее многочисленным из них является подрод Mentha, тогда как Pulegim включает два вида-M. pulegium и $M$. micrantha.

Обзор основных исследований по данной проблематике. Искусственным путем (с помощью колхицина) получены формы мяты некоторых культивируемых видов с числом хромосом 2n=I44-M. piperita $[2,3,4,5]$ и $2 \Pi=192-\mathrm{M}$. canadensis [6.] Эти исследования показывают, что в эволюции рода Mentha важная роль принадлежит полиплоидии. Для подрода Mentha, к которому относится большинство видов, основное число хромосом (х), вероятно, соответствует 6 или 12. Следует отметить, что в отношении положения рода Mentha в семействе Яснотковых (Губоцветных) существуют различные точки зрения, поскольку этот род сочетает наряду с прогрессивными чертами (сложное строение соцветия, высокий полиморфизм, женская двудомность, высокая полиплоидность, химическая, химическая разнокачественность) примитивную форму венчика [7].

Представители рода Mentha L. широко распространены на Земном шаре. Дикорастущие виды мяты произрастают преимущественно на увлажненных почвах в долинах рек, озер, на берегах водоемов и заболоченных территориях. Нередко дикорастущие виды можно встретить на суходолах в качестве сорных растений. Размножаются растения мяты в основном вегетативно-корневищами, рассадой и укорененными черенками.

Растения перечной мяты имеют однолетние стебли, у основания приподнимающиеся, четырехгранные, ветвистые, слабо опушенные, на зиму отмирающие Ветвление и месторасположение накрест супротивное Листья короткочерешковые, продолговатоэллиптической формы, заостренные на конце, а по краю-остро-зубчатые, темно-зеленой окраски. На нижней поверхности листа имеются железки и железистые волоски, в которых накапливается эфирное масло. Цветки мелкие, собраны в ложное колосовидное соцветие. Окраска венчика-светло-лиловая. Чашечка пятизубчатая, правильная, венчик почти простой, 4-х раздельный, мелкий (2,5-6,0 мм длиной), 4-е прямых одинаковых тычинок, тычиночная нить голая, к пыльникам прикрепляется посередине. Пыльники овальные, двухгнездные. Цветок имеет четырехгнездную завязь. В связи с гибридным происхождением M.piperita цветки у нее являются стерильными. У фертильной аллополиплоидной формы $M$. piperita после опыления в завязи образуется от 1 до 4-х плодов-орешков темнобурой окраски, всхожесть которых довольно низкая-до $30 \%$. Масса 1000 плодов- 0.065 г.

Отличительными признаками растений японской мяты, относящихся к виду M. canadensis (синоним-М. arvensis var. piperascens), является светло-зеленая окраска листовой пластинки, которая может быть как малоопушенной, так и сильноопушенной. Цветки лиловые или бледно-лиловые обычно собраны в цилиндрические цимозные соцветия с отстающими мутовкими.

Цветки M. canadensis являются стерильными, однако при переводе растений на полиплоидный уровень Л.А. Бугаенко [8] получены фертильные по женской линии формы, после искусственного опыления которых в 4-х гнездной завязи образуется до 2-4-х плодоворешков, отличающихся высокой всхожестью (до 80\%).

Определение цели статьи, постановка задач. Целью исследований являлось показать возможность использования дикорастущих видов мяты для создания межвидовых гибридов, обладающих устойчивостью к ржавчине и пониженным температурам.

Следует отметить, что для мяты характерно возникновение межвидовых гибридов в естественных условиях [1]. Гибридизация у мяты происходит в местах совместного произрастания различных видов и облегчается тем, что растения этого вида в основном являются перекрестноопыляющимися. Особенно часто происходит интрогрессивная гибридизация в дикорастущей флоре между $M$. aquatica и $M$. spicata, M. arvensis и $M$. longifolia, $M$. arvensis и M.aquatica. Обычно гибридный вид занимает экологическую нишу одного из родительских видов и является более устойчивым к поражению грибными и вирусными болезнями, являются более морозоустойчивыми. При этом не установлено какой-либо географической приуроченности цитотипов, поскольку 24-х хромосомный цитотип был выявлен как на территории Московской области, так и на территории Кавказа [7].

Изложение основного материала исследования. Мята культивируется для получения эфирного масла, основным и наиболее ценным компонентом которого является ментол, используемый в фармацевтической промышленности. Кроме того, мятное масло находит широкое применение в пищевой и парфюмерной промышленности.

Ментольная мята представлена в культуре двумя видами: Mentha piperita L., 2ח $=72$ и Mentha canadensis L., 2п =96. В.В. Макаров [1] к этому виду относит японскую мяту, иногда описываемую в литературе под названием M. arvensis var.piperascens Holm., 2ח=96 и сахалинскую мяту - M. sachalinensis Briq. (Kudo), $2 \Pi=96$.

На первых этапах (с 1923 года) селекционная работа проводилась с перечной мятой преимущественно клоновым методом, поскольку M.piperita проявляла полную стерильность, обусловленную ее гибридным происхождением. Указанный метод не дал хороших результатов, так как полученные клоны были низкоурожайными, имели низкое содержание эфирного масла и ментола, поражались ржавчиной, не обладали устойчивостью к низким температурам. 
В дальнейшем селекционная работа по мяте перечной была связана с использованием аллополиплоидииестественной [9] и экспериментальной [10]. Был получен ряд сортов (Прилукская-6, Краснодарская-2 и др.). В результате этого возросла урожайность и масличность исходного материала. Однако по ряду важнейших хозяйственно ценных признаков: содержанию ментола, устойчивости к болезням, вредителям и пониженным температурам все разнообразие исходного материала не выходило за пределы генотипа M. piperita.

Очевидно, невозможно было вопрос о повышении устойчивости к болезням, морозоустойчивости, повышению ментола в масле, не привлекая другие, в том числе и дикорастущие виды мяты. Тем более, что в роде Mentha отсутствует видовая несовместимость, а возникающая при отдаленной гибридизации стерильность гибридов F1 - не является препятствием для дальнейшего размножения выделившихся по комплексу хозяйственных признаков генотипов, поскольку мята размножается вегетативно. Однако широкому внедрению метода межвидовой гибридизации в селекционную практику по мяте должны были предшествовать генетические исследования, в первую очередь, касающиеся маслообразовательного процесса (закономерностей накопления эфирного масла и синтеза отдельных терпеновых компонентов), а также вопросов гетерозиса, изменчивости, наследования и наследуемости признаков, определяющих продуктивность.

Первые исследования генетических закономерностей накопления терпеноидов при межвидовых скрещиваниях, проведенные в 1954 году М.J. Murгay and R.H. Reisema [11], показали возможность использования этого метода для создания высокоментольных гибридов. Это позволило вести дальнейшую селекционную работу по мяте с привлечением метода межвидовой гибридизации.

Следует отметить, что одной из наиболее вредоносных болезней мяты является ржавчина, которая вызывается грибом Puccinia menthae Pers., и проявляется в виде оранжевых пустул, поражающих стебли и листья. При сильном поражении ржавчиной плантации мяты в среднем теряют до 25\% листьев, а во влажные годы потери составляют 50\% и более. Было установлено, что сорта мяты Прилукская-6 и Краснодарская-2, созданные на основе $M$. piperita, поражаются ржавчиной в значительной степени (от 50 до 90\%), также как сорта, полученные с участием М. arvensis var.piperascens в благоприятные для развития заболевания годы, имеют высокую поражаемость (до $100 \%)$.

Таким образом, создание сортов мяты, устойчивых к ржавчине, является весьма актуальной задачей, решение которой возможно только при углубленном изучении паразита, генетического и физиологического разнообразия его форм, а также типов устойчивости, характерных для различных видов и форм мяты, вовлекаемых в гибридизацию в целях селекции.

Гриб Puccinia mentha Pers поражает дикие и культурные растения семейства Lameaceae, в том числе и мяту, во всех частях земного шара. Установлено [12] 49 видов из 16 родов этого семейства, которые могут служить растениями-хозяевами для Puccinia menthae Pers. [13]. При проведении экспериментов по инокуляции с европейской коллекцией $P$. menthae [14] было установлено 8 физиологических рас, а в штате Нью- Иорк выявлено 6 физиологических рас ржавчины [15].

Последним автором была высказана мысль о существовании высокой степени специфичности различных форм ржавчины, т.е. патогенных рас может быть столько, сколько существует видов мяты. Однако детальные исследования, проведенные по изучению физиологической специализации внутри вида Puccinia Самарский научный вестник. 2015. № 2(11) menthae в Северной Америке [16], показали, что в этом районе существует 15 физиологических рас Puccinia menthae, 6 из которых распространены на мяте. При этом убедительно доказано, что формы от одного вида переносимы к некоторым другим видам рода Mentha и даже видам другого рода.

Генетические исследования на видах мяты в связи с поражаемостью ржавчиной (спикатно-мятной формой) были проведены M.J. Murray [17]. Опыты закладывались в Северо-Западной части штата Мичиган, где Pисcinia menthae f. piperita не распространена.

Изучалось 20 видов и форм мяты (So), их самоопыленные потомства (S1) и гибриды F1, полученные на их основе. Автор пришел к выводу, что иммунность к Puccinia menthaef. spicata, контролируется доминантным геном $\mathrm{S}$, который $\mathrm{y}$ выделенных иммунных форм находится в гомозиготном-SS ( M. piperita, $2 \mathrm{n}=72$, Mitcham, M. aquatica, $2 \Pi=96$, M. citrata) или гетерозиготном-Ss ( M. crispa, 2ח=48) состоянии. Восприимчивость к ржавчине контролируется рецессивным аллелем s, следовательно, виды, имеющие генетическую структуру ss (M. arvensis, M. arveneis var. piperascens, $2 \Pi=96$ (Японская мята), M. spicata, $2 \Pi=24$ и др.), являются восприимчивыми к заболеванию.

Таким образом, иммунность мяты к различным формам ржавчины контролируется моногенно, о чем свидетельствует характер расщепления в самоопыленных и гибридных потомствах [17]. При этом ген $\mathrm{S}$ контролирует иммунность к P. f. spicata. Это соответствует выдвинутой ранее [18] гипотезе о связи генов иммунности и восприимчивости со специфическими антигенами четырех форм ржавчины льна. Очевидно, другие гены (к настоящему времени еще не изученные) контролируют иммунность к остальным формам ржавчины: Рuccinia menthae f. piperita u Puccinia menthae f. arvensis.

В наших исследованиях использование в межвидовых скрещиваниях дикорастущих видов мяты, как доноров иммунности и устойчивости к ржавчине, основывалось на закономерностях генетического контроля биосинтеза терпеноидов и наследовании устойчивости к ржавчине при разных типах межвидовых скрещиваний. В связи с этим в лабораторных условиях изучали избирательную способность исследуемого материала к поражению различными формами ржавчины (Puccinia menthae f. spicata, а и P. mentbae f. piperita). Установлено, что такие родительские формы, как M. canadeneis К59, M. spicata Кб5 и К42, 2.8.14 (S1 К65) восприимчивы к Puccinia menthae, f.spicata и устойчивы к P. menthae $f$. piperita. a M.canadensis K60, M. aquatica К6 проявили полную устойчивость (иммунность) к обеим формам ржавчины. Гибридное потомство, полученное от скрещивания М. canadensis K60 (4n) и К59(4n) с растениями М. spicata $(\mathrm{K} 42, \mathrm{~K} 65,2.8 .14)$ и M. longifolia KI59, оказалось устойчивым к P. menthae f. piperita и в различной степени восприимчивым к $P$. menthae $f$. spicata. Гибриды, полученные от скрещивания M. canadensis K60 (4n) и К59 (4n) с иммунной формой $M$. aquatica К6, оказались полностью иммунными к обеим формам ржавчины. В таблице 1 представлены результаты оценки на устойчивость к ржавчине родительских форм и гибридов F1. Показано, что родительские формы имеют различную степень устойчивости: M. canadensis К60, используемая в качестве материнской формы, проявила полную полевую устойчивость (иммунность), в то время как у форм К59, K101 и КI03 отмечена высокая степень восприимчивости $(40,0-60,0 \%)$. У отцовских растений $M$. spicata степень поражаемости составила 40,0-42.1\%. У M. longifolia KI59-50,3\%, тогда как M. aquatica К6 проявила иммунность. При скрещивании М. canadensis К60, иммунной к ржавчине, с восприимчивыми отцовскими формами $M$. spicata $(\mathrm{M} 65, \mathrm{~K} 42,2.8 .14)$ и M. longifolia KI59 основная масса гибридов $(72,9-87,8 \%)$ характеризовалась полной 
устойчивостью, 5,2-23,0\% была практически устойчивы и 4, 1- 5, 7\% поражались в слабой и сильной степени

Совершенно другая картина наблюдается при скрещивании высоковосприимчивого материнского растения $M$. canadeneis K59 с перечисленными формами M. spicata и M. longifolia. Иммунных и практически устойчивых гибридов не выделено. Большая часть растений $(74,5-79,6 \%)$ этих комбинаций оказалась с высокой степенью поражения, 20, 4-25, 4\% гибридов со слабой степенью поражения. Несколько отличаются по поражаемости гибриды от скрещивания К59 х 2.8.14 В этой комбинации основной процент $(57,1 \%)$ составили слабопоражаемые гибриды при наличии $36,7 \%$ среднеи $5,5 \%$ сильнопоражаемых растений.

При скрещивании двух устойчивых форм (К60 х К6) почти все (94\%) гибриды проявили полную устойчивость к ржавчине. Вовлечение в скрещивания с иммунной формой $M$. aquatica К6 других форм М. canadenais-K101 и K103, поражающихся ржавчиной, также позволило получить устойчивое к ржавчине гибридное потомство.

Таблииа 1

Устойчивость родительских форм и гибридов F1 к ржавчине (естественный инфекционный фон)

\begin{tabular}{|c|c|c|c|c|c|c|c|c|}
\hline \multirow[t]{2}{*}{ Гибридные комбинации } & \multirow{2}{*}{$\begin{array}{l}\text { Изучено } \\
\text { гибридов }\end{array}$} & \multicolumn{2}{|c|}{$\begin{array}{c}\text { Степень } \\
\text { поражения } \\
\text { родительских форм }\end{array}$} & \multicolumn{5}{|c|}{$\begin{array}{c}\text { Процент гибридных растений с различной } \\
\text { степенью поражения }\end{array}$} \\
\hline & & + & $>$ & $0 \%$ & $1-10 \%$ & $11-30 \%$ & $31-50 \%$ & $\begin{array}{c}\text { 6ольше } \\
50 \%\end{array}$ \\
\hline $\mathrm{K} 60(4 \pi) \times \mathrm{K} 65$ & 286 & 0,0 & 42,1 & 87,8 & 5,2 & 3,9 & 1,8 & 1,3 \\
\hline $\mathrm{K} 60(4 \pi) \times \mathrm{K} 42$ & 224 & 0,0 & 40,0 & 84,4 & 11,6 & 3,6 & 0,4 & 0,0 \\
\hline $\mathrm{K} 60(4 \mathrm{I}) \times 2.8 .14\left(\mathrm{~S}_{1} \mathrm{~K} 65\right)$ & 96 & 0,0 & 41,6 & 72,9 & 23,0 & 3,1 & 1,0 & 0,0 \\
\hline $\mathrm{K} 60(4 \pi) \times \mathrm{KT} 59$ & 95 & 0,0 & 50,3 & 73,4 & 22,3 & 4,3 & 0,0 & 0,0 \\
\hline $\mathrm{K} 59(4 \pi) \times \mathrm{K} 65$ & 126 & 60,0 & 42,1 & 0,0 & 0,0 & 25,4 & 63,5 & 11,1 \\
\hline $\mathrm{K} 59(4 \pi) \times \mathrm{K} 42$ & 54 & 60,0 & 40,0 & 0,0 & 0,0 & 20,4 & 50,0 & 29,6 \\
\hline $\mathrm{K} 59(4 \mathrm{\pi}) \times 2.8 .14(\mathrm{~S} \mathrm{~K} 65)$ & 147 & 60,0 & 41,6 & 0,0 & 0,7 & 57,1 & 36,7 & 6,6 \\
\hline $\mathrm{K} 59(4 \pi) \times \mathrm{KIF9}$ & 90 & 60,0 & 50,3 & 0,0 & 1,1 & 14,4 & 60,0 & 24,5 \\
\hline$K 59(4 \pi) \times K 6$ & 97 & 60,0 & 0,0 & 87,6 & 12,4 & 0,0 & 0,0 & 0,0 \\
\hline $\mathrm{K} 60(4 \pi) \times \mathrm{K} 6$ & 83 & 0,0 & 0,0 & 94,0 & 6,0 & 0,0 & 0,0 & 0,0 \\
\hline $\mathrm{KIOI} \times \mathrm{K} 6$ & 32 & 65,0 & 0,0 & 84,4 & 15,6 & 0,0 & 0,0 & 0,0 \\
\hline $\mathrm{KI} 03 \times \mathrm{K} 6$ & 33 & 46,0 & 0,0 & 82,0 & 19,0 & 0,0 & 0,0 & 0,0 \\
\hline Прилукская-6 & контроль & 30,0 & & & & & & \\
\hline
\end{tabular}

Таким образом, наиболее устойчивыми к ржавчине оказались гибридные потомства, полученные с участием иммунных форм $M$. canadensis К60 и M. aquatica К6. Анализ расщепления по устойчивости к ржавчине показал, что при скрещивании К60 х М. spicata и M. longifolia большая часть растений (около 3/4) является иммунной к ржавчине, а остальные поражаются. В потомстве от скрещивания К59 х К6 и К60 х К6 все гибриды устойчивы. Такой характер расщепления свидетельствует о том, что признак иммунности доминирует над восприимчивостью, что подтверждает данные, полученные М.J. Марреем [17] B соответсхвии с этим в потомстве F1 при скрещивании сильно восприимчивой к $P$. menthae $f$. spicata формы К59 с иммунной $M$. aquatica К6 большая часть (до $80 \%$ ) гибридов проявляют иммунность. При этом родительские формы имеют гомозиготный доминантный SS (K6) и гомозиготный рецессивный ssss (K59) генотипы. M. canadeneis K60, очевидно, является гетерозиготной по гену, контролирующему устойчивость к $P . f$. spicata (генотип SSss), в результате чего в гибридном потомстве F1 от скрещивания К60 $x$ M. spicata выщепляются растения, поражающиеся ржавчиной. Гетерозиготность формы К60 по этому признаку также подтверждается анализом устойчивости ее самоопыленного потомства, в котором наблюдается расщепление на иммунные и восприимчивые растения.
При скрещивании двух устойчивых форм К60 х К6 расщепления по устойчивости к ржавчине в гибридном потомстве не происходит, что находится в соответствии c их генетической структурой. Использование в качестве материнского родителя поражающейся формы К59 при скрещивании с К6 значительно не уменьшило числа устойчивых гибридов, поскольку все они имели гетерозиготный генотип Ss.

Таким образом, в результате проведенных нами исследований показано, что межвидовая гибридизация у мяты при соответствующем подборе родительских пар является ценным методом создания устойчивых к ржавчине (Puccinia menthae Pers) высокопродуктивных гибридов. Подтвержден моногенный характер наследования иммунности к Puccinia menthae Pers и определен генотип родительских форм M. canadensis, M..aquatica, M.spicata по гену S, наличие доминантных $(\mathrm{S})$ или рецессивных аллелей (s) в гомозиготном (SS,SSSS,ss) или гетерозиготном состоянии (Ss, SSss) определяет выраженность этого признака в гибридном потомстве. Рекомендованы наиболее перспективные комбинации межвидовых скрещиваний для селекции мяты на устойчивость к ржавчине.

Одной из биологических особенностей перечной мяты и ее сортов является низкая морозоустойчивость корневищ, тогда как дикорастущие формы M. picata, M gentilis, некоторые формы M. longifolia широко распространены и обладают высокой морозоустойчивостью.

В селекции на морозоустойчивость так же, как и на устойчивость к ржавчине, перспективным является метод межвидовой гибридизации, позволяющий вносить в создаваемые гибриды гены устойчивости, которыми обладают некоторые дикорастущие виды мяты.

Для решения вопроса создания сортов мяты с повышенной морозоустойчивостью нами [19] впервые был использован метод межвидовой гибридизации с привлечением в скрещивания дикорастущих морозоус-тойчивых форм M. spicata. Одной из таких форм является мята Приднепровская (М. spicata К65), широко распространенная на Украине и являющаяся, благодаря своей повышенной морозоустойчивости, злостным засорителем плантаций сортовой мяты. Другая морозоустойчивая форма M. spicata K42 была выделена нами при изучении коллекции дикорастущих видов и форм мяты. Для установления характера наследования морозоустойчивости в потомстве F1, кроме указанных выше форм, в скрещивания с M. piperita (4п) вовлекалась форма $M$. spicata K40, отличающаяся так же, как и M. piperita, пониженной морозоустойчивостью. Морозоустойчивость корневищ районированного сорта Краснодарекая-2 приближалась к материнской форме $M$. piperita . О степени морозоустойчивости корневищ гибридов, родительских форм и контроля Краснодарекая-2 судили по результатам сохранения живых глазков после искусственного замораживания в холодильной камере, а также по результатам определения суммарного сопротивления тканей корневищ (импеданса), которое принимали за относительный показатель морозоустойчивости. Показатели импеданса корневищ аллополиплоидной формы перечной мяты, которая использовалась в скрещиваниях в качестве материнской формы, колебалась в пределах 32,4-32,6 ком, у отцовской формы M. spicata K65 в пределах 39,3-40,1 ком, у M. spicata K42-43,4-43,7 ком, у М. spicata K40-27,4-32,1 ком.

Показатели импеданса у гибридов от скрещивания А2 х К65 варьировали в пределах 30,0-41,1 ком. В этой комбинации только $4 \%$ гибридов имели показатели импеданса, приближающиеся к неморозоустойчивой материнской форме. Остальная часть гибридов по данному признаку занимала промежуточное положение между родительскими формами. Однако значительное Самарский научный вестник. 2015. № 2(11) 
количество гибридов (36\%) показателям импеданса к морозоустойчивой отцовской форме (табл. 2).

У гибридов от скрещивания А2 х К42 наблюдалось варьирование показателей импеданса в пределах $30,2-43,3$ ком. Незначительное количество (3\%) гибридов этой комбинации имело импеданс на уровне неморозоустойчивой материнской формы. Остальная часть гибридов по показателям импеданса занимала промежуточное положение между родительскими формами. Гибридов, приближающихся по данному признаку к морозоустойчивой отцовской форме, в указанной комбинации меньше, чем в предыдущей $(22 \%$ от общего числа гибридов).

У гибридов от скрещивания А2 х К40 показатели импеданса варьируют в пределах 31,4-37,2 ком, 5,8\% гибридов имели импеданс на уровне неморозоустойчивой материнской формы и столько же на уровне морозоустойчивой отцовской формы. Остальные гибриды имели более высокие показатели импеданса по сравнению с родительскими формами. Однако гибридов с повышенными показателями импеданса, приближающимися к Приднепровской мяте, в данной комбинации обнаружено не было. Основной процент (54\%) гибридов имели импеданс в пределах $33,6-35,5$ ком, т.е. находился на уровне районированного сорта Краснодарская-2.

Таким образом, при изучении показателей импеданса тканей корневищ у исследуемых комбинаций выявлено, что наибольшее количество форм, имеющих высокие показатели импеданса, обнаружено в комбинации А2 х К65. Несколько меньше таких гибридов выявлено при скрещивании А2 х К42. В случае скрещивания аллополиплоидной формы перечной мяты с неморозоустойчивой формой M.spicata K40 гибриды с повышенными показателями импеданса выделены не были.

Критерием оценки корневищ мяты на морозоустойчивость при прямом методе было количество живых глазков в\%, оставшихся после промораживания при температуре $-8^{\circ} \mathrm{C}$ в течение 7 суток. Подсчет живых глазков (почек), оставшихся после промораживания, показал, что, в основном, гибриды по данному признаку занимали промежуточное положение между неморозоустойчивой аллополиплоидной формой M.. piperita и морозоустойчивой M. spicata K65.

Значительное количество форм $(78,6 \%)$ после промораживания превышало по количеству живых глазков районированный сорт Краснодарская-2.

Таблииа 2

Характер наследования морозоустойчивости межсидовыми гибридами F1, полученными от скрещиивания M. piperita, 4n (A2) x M. spicata

\begin{tabular}{|c|c|c|c|}
\hline \multirow{2}{*}{ Тип наследования } & \multicolumn{3}{|c|}{ Количество гибридов (\%), имеющих определенный тип наследования } \\
\cline { 2 - 4 } & $\mathrm{A}_{2} \times$ К65 & $\mathrm{A}_{2} \times$ К 42 & $\mathrm{~A}_{2} \times$ К 40 \\
\hline Превысили лучшего родителя & 0,0 & 0,0 & 80,4 \\
\hline Равны лучшему родителю & 36,6 & 22,0 & 13,8 \\
\hline Промежугочный & 60,0 & 75,0 & 0,0 \\
\hline Равны худшему родителю & 4,0 & 3,0 & 5,8 \\
Ниже худшего родителя & 0,0 & 0,0 & 0,0 \\
(депрессия) & 50,0 & 60,0 & 22,0 \\
Превзошли стандарт & &
\end{tabular}

С целью установления коррелятивной зависимости между морозоустойчивостью гибридных растений и импедансом тканей корневищ проводилось сопоставление результатов измерения импеданса тканей корневищ с их фактической морозоустойчивостью, т.е. показателями процента живых глазков, оставшихся после промораживания корневищ в холодильной камере.

Расчет величины корреляции между показателями импеданса тканей корневищ и их морозоустойчивостью, проведенный с помощью метода ранговых корре- ляций [20], показал, что у гибридов от скрещивания М. piperita c M. spicata К65 и К42 существует довольно высокая коррелятивная зависимость- 0,77 и 0,74 (табл.3). У гибридов третьей комбинации от скрещивания двух неморозоустойчивых сортов эта корреляционная зависимость выражена слабее - $(0,30 \pm 0,14)$.

Коррелящионная зависимость между величиной импеданса тканей корневищ гибридных растений и их морозоустойчивостью

Примечание: $х$ значимо на 5\%-ом уровне значимости; хх значимо на 1\%-ом уровне значимости

\begin{tabular}{|c|c|c|c|}
\hline \multirow{2}{*}{ Комбинации скрещиваний } & Импеданс (Z ком) & $\begin{array}{c}\% \text { сохранившихся } \\
\text { глазков }\end{array}$ & $\begin{array}{c}\text { Коэффициент } \\
\text { корреляции }\end{array}$ \\
\hline & $\mathrm{X} \pm \mathrm{S}_{\mathrm{L}}$ & $\mathrm{X} \pm \mathrm{S}_{\mathrm{x}}$ & $\mathrm{P}^{\mathrm{s}} \pm \mathrm{mp}$ \\
\hline M.piperita $\left(\mathrm{A}_{2}\right) \times$ M.spicata $\mathrm{K} 65$ & $36,4 \pm 0,46$ & $43,0 \pm 2,23$ & ${ }^{\mathrm{m}} 0,77 \pm 0,07$ \\
\hline M.piperita $\left(A_{2}\right)$ M M.spicata K 42 & $35,9 \pm 0,48$ & $36,2 \pm 2,27$ & ${ }^{\text {II } 0,74 \pm 0,07}$ \\
\hline M.piperita $\left(A_{2} \times\right.$ M.spicata $K 40$ & $34,5 \pm 0,19$ & $26,9 \pm 2,04$ & ${ }^{x} 0,30 \pm 0,14$ \\
\hline
\end{tabular}

Проведенное нами изучение импеданса тканей корневищ гибридных растений мяты и сопоставление полученных результатов с их фактической морозоустойчивостью (данные прямого промораживания корневищ в холодильной камере) показало, что величина импеданса тканей корневищ может служить объективной характеристикой при оценке гибридных растений по этому показателю. В селекционном процессе, когда возникает необходимость оценить на морозоустойчивость большой объем растений, определение импеданса тканей может служить в качестве эффективного метода для предварительной оценки селекционного материала.

Следует отметить, что гибриды, полученные от скрещивания $M$. piperita (4п) с морозоустойчивыми формами $M$. spicata, в основном имели ментольное направление биосинтеза эфирного масла, однако содержание ментола не превышало $62,2 \%$.

Изучение изменчивости и наследования основных хозяйственно ценных признаков у межвидовых гибридов представляет практический интерес с точки зрения установления перспективности гибридных комбинаций и возможности выделения в F1 высокопродуктивных гибридов с повышенной морозоустойчивостью, которые могли бы служить ценным исходным материалом в селекции мяты. В результате наших исследований было установлено, что в F1 межвидовых гибридов от скрещивания аллополиплоидной формы перечной мяты с морозоустойчивыми растениями M. spicata признак морозоустойчивости наследуется в основном по промежуточному типу, однако до $30 \%$ растений приближается по этому признаку к морозоустойчивому родителю. Это указывает на возможность получения межвидовых гибридов с повышенной морозоустойчивостью при указанном типе скрещиваний.

В связи с задачами селекции мяты наряду с высокой ментольностью и масличностью вновь создаваемые сорта должны обладать устойчивостью к ржавчине, а для возделывания на севере Украины и России-высокой морозоустойчивостью. Разработанный метод направленного подбора родительских пар по компонентному составу эфирного масла позволяет использовать для этих целей богатый генофонд дикорастущих видов и форм мяты, в котором встречаются генотипы, обладающие генами устойчивости к болезням и пониженным температурам. Для изучения возможности сочетания в одном гибридном генотипе, наряду с хорошим качеством и масличностью, устойчивостью к ржавчине и морозоустойчивостью, были изучены закономерности наследования этих признаков при межвидовых скрещиваниях. Показано, что они имеют различную генетическую детерминацию, 
в связи с чем проявляют различный характер наследования в F1. Признак морозоустойчивости в потомстве F1 имеет непрерывную изменчивость и наследуется по промежуточному типу, поскольку имеет полигенную природу. Выраженность этого признака в сильной степени зависит от уровня морозоустойчивости родительских форм, что говорит об аддитивном характере действия генов. Установлено, что в потомстве F1 межвидовых гибридов возможно выделение до 30\% гибридов с повышенными показателями морозоустойчивости. Для создания гибридов с повышенной морозоустойчивостью перспективно использование в межвидовых скрещиваниях морозоустойчивых форм М. spicata K42, К65, линий S1 и S2 , полученных от самоопыления К65 (2.8.I4, 9.37.34), а также полиплоида М. canadensis К60.

Вывводы и перспективы дальнейших изысканий.

1.Показано, что межвидовая гибридизация у мяты при соответствующем подборе родительских пар является ценным методом создания устойчивых к ржавчине (Puccinia menthae Pers) высокопродуктивных гибридов. Подтвержден моногенный характер наследования иммунности к Puccinia menthae Pers и определен генотип родительских форм $M$. canadensis, $M$. aquatica, $M$. spicata по гену $\mathrm{S}$,

2. Наличие доминантных $(\mathrm{S})$ или рецессивных аллелей (s) в гомозиготном (SS, SSSS, ss) или гетерозиготном состоянии (Ss, SSss) определяет выраженность этого признака в гибридном потомстве F1.

3. Выявлены доноры устойчивости к ржавчине-М. canadensis K60 (4п) и М. aquatica К6, которые в широком спектре комбинаций обеспечивают устойчивость к ржавчине основной массы гибридного потомства.

4. Установлено, что в F1 межвидовых гибридов от скрещивания аллополиплоидной формы перечной мяты с морозоустойчивыми растениями $M$. spicata признак морозоустойчивости наследуется в основном по промежуточному типу, однако до $30 \%$ растений приближается по этому признаку к морозоустойчивому родителю. Это указывает на возможность получения межвидовых гибридов с повышенной морозоустойчивостью при указанном типе скрещиваний.

5. Для создания гибридов с повышенной морозоустойчивостью перспективно использование в межвидовых скрещиваниях морозоустойчивых форм M. spicata $\mathrm{K} 42, \mathrm{~K} 65$, линий S1 и S2 , полученных от самоопыления K65 (2.8.I4, 9.37.34), а также полиплоида M. canadensis K60.

6. Создан генофонд дикорастущих видов и форм мяты, в котором представлены генотипы, обладающие генами устойчивости к болезням и пониженным температурам.

\section{СПИСОК ЛИТЕРАТУРЫ}

1. Макаров В.В. Дикорастущие мяты СССР // Автореф. дис.... канд. биол. наук. М. 1972. 36 с.

2. Глотов В.В. Амфидиплоидная плодовитая форма M. piperita L., полученная после обработки колхицином // Доклады АН СССР.- 1940. Т. 28. №5. С. 449-452.
3. Лутков А.Н. Экспериментальное получение полиплоидной формы перечной мяты-Mentha piperita L. // Краткий отчет о научно-исследовательской работе за 1956 г.-Краснодар: Советская Кубань. 1957, С. 112-115.

4. Адмиральская С.А. Цитолого-эмбриологический анализ развития цветка новой аллополиплоидной формы перечной мяты // В кн: Сборник научно-исследовательских работ по масличным и эфиромасличным культурам.-М., 1960. С. 207-216.

5. Адмиральская С.А. Стерильность перечной мяты и ее преодоление // Автореф. дис. ... канд. биол. наук.-Л.1960. 17 с.

6. Бугаенко Л.А., Теплицкая Л.М., Резникова С.А. Влияние полиплоидии на накопление эфирного масла у высокоментольных форм мяты // В кн.: 111 съезд Всесоюзного общества генетиков и селекционеров им.Н.И. Вавилова. Тез. докл. Л.: Наука. 1977. Ч. 1. С. 73- 74.

7. Кириченко Е.Б. Экофизиология мяты: продукционный процесс и адаптационный потенциал. М.: Наука, 2008. $140 \mathrm{c}$.

8. Бугаенко Л.А. Генетические закономерности биосинтеза терпеноидов и перспективы регуляции содержания и качества эфирного масла при межвидовой гибридизации у мяты // Дис. ... д-ра биол. наук. 1985, М. 440 с.

9. Корнева Е.И., Резникова С.А. Естественная полиплоидия в селекции мяты перечной // Агробиология. 1965. №3.C. 454-455.

10. Глотов В.В. Амфидиплоидная плодовитая форма M. piperita L., полученная после обработки колхицином // Доклады АН СССР. 1940. Т. 28. №5. C. 449-452.

11. Murray M.J., Reitsema R.H. The genetic basis of ketones, carvone, and menthone in Mentha crispa L. // J. Amer. 1954. V.-XL111. №10. P. 612-613

12. Sydow R., Sydow H. Monografia Uredinearum I. // Gebrüder Bortraeger. Leipzig. 1904. 58 p.

13. Fisher E. Die Uredineen der schwis // Bern. 1904.590 p.

14. Cruchet P. Cjntributions a letude biologique de quelgues Puccinies sur Labiees // Central f. Bakt. 1906. Abt.11. Teil 17. S. 212-224.

15. Hiederhauset G.S. The rust of greenhouse-grown spearmint and its control // Cornel.Univ. Agr. 1945. Exp.Sta. Mem. 263 p.

16. Bahter I.W., Cummins G.B. Physiologic specialization in Puccinia menthae Pers and notes on eiphytology // Phytopathology. 1953. V. 43. №4. P. 178-180.

17. Murray M.J. Spearmint rust resistance and immunity in the genus Mentha // Crop. Scince. 1961.V. 1. P. 175-179.

18. Doubly G.A., Flor H.H., Glagett C.O. Relation of antigens of Melampora lini and linum usitatissimum to resistance and susceptibility // Science. 1960. Р. 131-229.

19. Бугаенко Л.А. Межвидовая гибридизация как метод создания морозоустойчивых, высокопродуктивных сортов мяты // Автореф. дис.... канд. биол. наук. Киев. 1976. $23 \mathrm{c}$

20. Урбах В.Ю. Биометрические методы // М.: Наука. 1964. $415 \mathrm{c}$.

\section{WILD-GROWING SPECIES OF MINT AS CARRIERS OF GENES OF RESISTANCE TO ADVERSE ENVIRONMENTAL FACTORS}

(C) 2015

Bygayenko L.A., Doctor of Biological Sciences, Professor at the Department of Biology, Ecology and Safety

Crimean Engineering and Pedagogical University, Simferopol, Republic of Crimea (Russia)

Annotation. It is shown wild-growing types of mint can be carriers of genes of frost resistance and resistance to rust which is caused by a mushroom of Puccinia menthae Pers. The method of interspecific hybridization with use of the cultivated types-Mentha piperita and Mentha canadensis L., and also wild-growing types-Mentha aquatica L., Mentha spicata L. and Mentha longifolia (L.) Nathh is perspective for creation of steady grades. Sustainability donors to a rust-M. canadensis K60 (4p) and K6 M. aquatica which in a wide range of combinations provide resistance to a rust of bulk of hybrid posterity have been revealed.

Interspecific hybridization at mint at the corresponding selection of parental couples is a valuable method of cre- 
ation of highly productive hybrids, steady against a rust (Puccinia menthae Pers) that has been shown.. Monogenic nature of inheritance of an immunity to Puccinia menthae Pers is confirmed and the genotype of the parental forms M. canadensis, M.aquatica, M.spicata is determined by S gene, Existence of prepotent (S) or recessive alleles (s) in homozygous (SS,SSSS,ss) or a heterozygotic state (Ss, SSss) expressiveness of this sign in hybrid posterity of F1 defines.

It is established that in F1 of interspecific hybrids from crossing of an allopolyploid form of a pepper mint with frost resistance plants of M. spicata it is frost resistance sign inherited generally on intermediate type, however to $30 \%$ of plants comes nearer on this sign to the frost-resistant parent. It indicates possibility of receiving interspecific hybrids with increased frost resistance at the specified type of crossings.

For creation of hybrids with the increased frost resistance use in interspecific hybridization of the frost-resistant forms M. spicata K42, K65, the S1 and S2 lines received from self-pollination of K65 (2.8.I4, 9.37.34), and also a polyploidy of M. canadensis of K60 is perspective.

The gene pool of wild-growing types and forms of mint in which the genotypes possessing genes of resistance to rust and the lowered temperatures are presented is created.

Keywords: interspecific hybridization; types of mint; resistance to rust; frost resistance; stability genes; gene pool; polyploids.

\title{
УДК 579.26 \\ ТЕРМОФИЛЬНЫЕ ОРГАНОТРОФНЫЕ БАКТЕРИИ РОДА МЕIОТНЕRМUS В ЩЕЛОЧНЫХ ГИДРОТЕРМАХ ПРИБАЙКАЛЬЯ (БУРЯТИЯ)
}

(C) 2015

\author{
В.Г. Будагаева, аспирант лаборатории микробиологии \\ Институт общей и экспериментальной биологии СО РАН, Улан-Удэ (Россия) \\ Д.Д. Бархутова, кандидат биологических наук \\ Институт общей й экспериментальной биологии СО РАН, Улан-Удэ (Россия)
}

Аннотация. В донных осадках и микробных матах щелочных термальных источников Прибайкалья (Бурятия) широко распространены аэробные, факультативно анаэробные гидролитические бактерии.

Типичными представителями бактерий-гидролитиков являются алкалотермофильные бациллы, способные утилизировать органические вещества в щелочных водах горячих источников. Из микробного мата термальных источников Прибайкалья (Бурятия) выделены в чистую культуру 2 штамма бактерий, растущих на ацетате, пирувате и соетоне, представлены неспорообразующими прямыми или изогнутыми удлиненными палочками, которые были морфологически близки к представителям рода Meiothermus. На агаризованной среде бактерии образовывали мелкие гладкие колонии розового цвета. Изучены экофизиологические свойства (отношение к температуре и pH) выделенных изолятов. Для культуры Um-14-2-1 оптимальная температура роста была 450C, диапазон температур составил 35-600С. Температурный диапазон развития для штамма Al-14-3 составил 30-60 ${ }^{\circ}$, с оптимумом $50^{\circ} \mathrm{C}$. Диапазон рН штамма Um-14-2-1 от 6,5 до 9,5, оптимум 8,0. Диапазон рН штамма Al-14-3 от 6,5 до 9,5, оптимум 8,5. По морфофизиологическим свойствам и способности к термофилии 2 культуры гетеротрофных бактерий сходны с представителями рода Meiothermus и являются умеренными термофилами.

Ключевые слова: гидротермы; микробные маты; гетеротрофы; термофилы; оптимум температур; алкалофилы; Meiothermus; экофизиология.

Термальные источники являются уникальными водными экосистемами, характеризующиеся высокой температурой и высокими значениями $\mathrm{pH}$, которые создают благоприятные условия для развития термофильных и алкалифильных прокариот в водной толще и донных отложениях. Азотные термальные воды формируются в зонах тектонических разломов и имеют сульфатный, сульфатно-гидрокарбонатный или гидрокарбонатносульфатный натриевый состав [1, с. 54-60]. Микробные сообщества, формирующиеся в этих водах, представляют собой полноценные функциональные системы, эффективно осуществляющие круговорот биогенных элементов в процессах продукции и деструкции органического вещества [2, с. 579-600].

Органотрофные термофильные бактерии осуществляют деструкцию органических веществ, осуществляемую различными функциональными группами микроорганизмов [3, с. 35-47].

Распространение аэробных бактерий-деструкторов органического вещества ранее было изучено в гидротермах Прибайкалья и Монголии [4, с. 143-157].

Впервые была выделена и описана новая алкалофильная аэробная органотрофная бактерия T. ruber из горячих источниках Бурятии: Алла и Гусиха [5, с. 498- 499]. В отличие от известных ранее видов этого рода, Т. ruber рос оптимально при 60-650С, т.е. являлся умеренным термофилом. Впоследствии он был перенесен в новый род семейства Thermaceae-Meiothermus [6,c. 604-606]. Представители рода Meiothermus встречаются, как правило, в бедных питательными веществами средах обитания. Они широко распространены в горячих природных или искусственных средах обитания, таких, как бытовые и промышленные системы горячей воды или ферментеры, работающие при высоких температурах [7, с. 1647-1654; 8, с. 1225-1230]. Интересно, что виды Meiothermus, кроме того, что были найдены в больших количествах в промышленных условиях, например, в системах сточных вод и системах хранения ядерного топлива [9, с. 727-740], также были выделены в качестве основных представителей биопленок бумагоделательных машин, так как крахмал является легко доступным источником углерода [10, с. 225-238; 11, c. 1228-1235].

Они является облигатными аэробами, способными расти при температуре от $35-700 \mathrm{C}$, оптимальная температура роста варьирует от 50 до 650C [12,c. 840- 844;13, с. 306-313]. Как было показано, представители рода Meiothermus образуют палочки, выстраивающиеся в нити и, как правило, формируют красные или желтые колонии $[14$, с. $3745-3753 ; 15$, с. 39-45; 16 , с. 143-150]. Все известные виды рода Meiothermus гидролизуют белки и пептиды, некоторые используют также крахмал. В качестве источника углерода и/или энергии бактерии используют дисахариды, аминокислоты, органические кислоты гексозы, некоторые пентозы [17,c. 243-246]. Meiothermus spp. часто связаны с фотосинтезирующими и хемолитотрофными прокариотами. Считается, что такие ассоциации обеспечивают продолжительно низкие концентрации органических соединений, что является полезным для их роста, так как воздействие высоких концентраций органических веществ является ингибирующим [18, с. 274-278].

Объектами исследования являлись термальные источники-Алла и Умхэй, расположенные у подножия 